\title{
Evaluation of Municipal Solid Waste Management Practices for an Industrialized City
}

\author{
İsmail Özbay* \\ Department of Environmental Engineering, Faculty of Engineering, Kocaeli University, 41380, Kocaeli, Turkey
}

Received: 26 May 2014

Accepted: 23 September 2014

\begin{abstract}
Increasing amounts of solid wastes cause serious environmental problems, especially for industrialized cities. Kocaeli, one of the most industrialized cities of Turkey, can be evaluated as a representative sample of this situation. In the city, uncontrolled disposal of municipal solid wastes (MSW) can threaten the ecological environment. In this context, the application of integrated solid waste management carries importance for preventing harmful effects.

This paper presents four basic strategies of integrated municipal solid waste management as evaluated for Kocaeli: 1) source reduction, 2) recycling and composting, 3) material recovery and thermal conversion (incineration), and 4) sanitary landfilling. Solid waste management applications from 2006 to 2012 have been investigated and projections have been made for the future. Results of the study showed that integrated solid waste management has been based on sanitary landfilling, even in Kocaeli. Also, there are significant problems about separation at source in recycling actives as there is no legal regulation. Unfortunately, significant amounts of valuable materials are sent to landfills every year.
\end{abstract}

Keywords: municipal solid waste, waste management, sanitary landfilling, recycling, Kocaeli

\section{Introduction}

Rapid urbanization, increasing population, and developing living standards have created large amounts of solid wastes all over the world [1]. 14.43 and 10.84 million tons of municipal solid waste (MSW) were generated, respectively, in summer and winter seasons of 2010 in Turkey. Solid waste generation rates were calculated as $1.14 \mathrm{~kg}$ per capita per day for the country [2]. In literature it is estimated that the annual growth rate of MSW is $3.2-4.5 \%$ for developed countries and 2-3\% for developing countries [3].

Continuously increasing amounts of solid wastes threaten human health and ecological environment [4]. Although important technological and regulatory improvements have been achieved, disposal and treatment facilities are still inadeqaute in many countries, considering adverse health

*e-mail: ismail.ozbay@yahoo.com effects coming from the wastes [5]. In Turkey, the accident at the Umraniye-Hekimbaşı open dumpsite on 28 April 1993, which was caused by the explosion of gases compressed within the dumping area, resulted in the death of 40 citizens [6]. This accident was the starting point for considering the solid waste problem for Turkey.

Waste generation, transportation, treatment, and disposal are the main processes within an MSW management system [7]. Ideal treatment and disposal processes may require various management options, such as source reduction, curbside recycling, material recovery, waste-to-energy, sanitary landfilling, and composting [8]. In Turkey, about $34.63 \%$ of the wastes were disposed at in dumping sites belonging to small municipalities, $7.23 \%$ of wastes were disposed of in dumping sites belonging to metropolitan municipalities, $54.39 \%$ of wastes were disposed in sanitary landfills, $1.66 \%$ of wastes were disposed at in dumping sites belonging to another municipality, $0.77 \%$ of wastes 
were composted, $0.53 \%$ of wastes were burned in an open area, $0.17 \%$ of wastes were disposed into rivers, $0.13 \%$ of wastes were buried, and the remaining wastes were disposed of using other methods [2].

Landfilling is a widespread method in waste management applications of Turkey. As known, the landfilling process is one of the major sources of greenhouse gases. It has been determined, for example, that $25 \%$ of methane gas is coming from landfills in England [9]. Nowadays different landfill gases (LFG) have been used within energy recovery systems and significant amounts of electrical power have been generated this way [10]. $1 \mathrm{MW}$ of electricity can be produced from approximately $500 \mathrm{~m}^{3} / \mathrm{h}$ of LFG with 50\% methane content [11]. Brazil produces 69 MW of power through the utilization of LFG, although it has been estimated that the country has the potential for about 660 MW of electrical power from landfills [12].

Several methods have been found to be more sustainable than landfilling, such as incineration-producing energy, composting of organic wastes, and material recovery through recycling. Among these methods, recycling is accepted as one of the most environmentally frendly strategies as it provides reduction in consumption of sources and allows energy savings [13, 14]. So this method should absolutely be involved in waste management systems [15]. The EU strategy on waste recycling ensures a recycling society that will use the waste as a resource [16].

Composting also has been presented as an environmentally friendly and sustainable alternative to manage organic solid wastes. This technique aims to obtain a high quality organic product that can be used as an organic amendment in agriculture [17]. In solid waste management applications, incineration is another important process providing significant volume reduction $[18,19]$. MSW is regarded as a promising fuel in European countries with the heating capacity from 7.2 to $14.9 \mathrm{GJ} / \mathrm{t}$ [20]. In Denmark, $5 \%$ of total electricity and $20 \%$ of the total district heating was supplied from incineration in 2011 [21]. There is no practice of MSW incineration for Turkey, but in 2006 approximately 11 million tons of solid waste were disposed of by incineration in China. Energy obtained by incineration of MSW provides an economical benefit of $0.04 \$$ per KWh for a 15 year period [22]. Although remarkable energy generation can be obtained by utilization of LFG gases [12], incineration technology yields more economical benefits compared to the landfilling option considering the amount of the generated energy [23]. Due to advantages of energy supply and waste volume reduction, incineration is widely suggested for future applications.

Applications on integrated solid waste management systems are affected by many factors such as regulations of countries, environmental conditions, environmental management strategies, energy policies, economic and technical practicability, education level, and environment conscious of the public [24]. These effective factors cause important variations in MSW management policies for different countries. For example, in China huge amounts of MSW have been generated as a result of continuously developing living standards. In that country, incineration is playing an impor-
Table 1. Comparison of MSW treatment methods and disposal rates ( $\%$ of MSW) for European countries and Turkey.

\begin{tabular}{|c|c|c|c|c|}
\hline National & Landfill & Incineration & Compost & Recycle \\
\hline Austria & 3 & 35 & 34 & 28 \\
\hline Belgium & 1 & 42 & 21 & 36 \\
\hline Bulgaria & 73 & 0 & 3 & 24 \\
\hline Cyprus & 79 & 0 & 9 & 12 \\
\hline Czech Republic & 56 & 20 & 3 & 21 \\
\hline Denmark & 3 & 52 & 13 & 32 \\
\hline Estonia & 44 & 16 & 6 & 34 \\
\hline Finland & 33 & 34 & 12 & 21 \\
\hline France & 28 & 33 & 16 & 23 \\
\hline Germany & 1 & 35 & 18 & 46 \\
\hline Greece & 82 & 0 & 2 & 16 \\
\hline Hungary & 65 & 9 & 5 & 21 \\
\hline Ireland & 39 & 16 & 8 & 37 \\
\hline Italy & 41 & 20 & 15 & 24 \\
\hline Latvia & 84 & 0 & 2 & 14 \\
\hline Lithuania & 79 & 1 & 2 & 18 \\
\hline Luxemburg & 18 & 36 & 18 & 28 \\
\hline Malta & 87 & 0 & 4 & 9 \\
\hline Netherlands & 2 & 49 & 25 & 24 \\
\hline Poland & 75 & 1 & 11 & 13 \\
\hline Portugal & 54 & 19 & 15 & 12 \\
\hline Romania & 99 & 0 & 0 & 1 \\
\hline Slovakia & 77 & 10 & 7 & 6 \\
\hline Slovenia & 50 & 2 & 6 & 42 \\
\hline Spain & 62 & 10 & 11 & 17 \\
\hline Sweden & 1 & 52 & 15 & 32 \\
\hline Turkey & $90^{\mathrm{a}}$ & $0^{\mathrm{a}}$ & $1^{\mathrm{a}}$ & $9^{b}$ \\
\hline United Kingdom & 37 & 17 & 18 & 28 \\
\hline
\end{tabular}

Source: Eurostat, Municipal Waste Statistics in 2012.

${ }^{a}$ State Institute of Statistics of Turkey, Environmental Statistics in 2008.

${ }^{\mathrm{b}}$ Ministry of Environment and Forestry, Waste Management Application Plan between for 2008-12.

tant role in MSW management as it provides important volume reduction. Treatment capacity of $33.010 \mathrm{t} / \mathrm{d}$ has been achieved in the country with $67 \mathrm{MSW}$ incinerators [19].

Open dumping is widely used in underdeveloped countries having lower budgets for MSW management. In SubSaharan African cities, MSW management is a challenging topic for both residents and authorities. As a result of inadequate MSW collection, residents may have to cope with 
refuse heaps. Finally, they are burned under uncontrolled conditions or dumped in streams and stagnant gutters [25]. Similarly, MSW management has been a challenging environmental issue in Tulsipur, Nepal. All of the generated MSW was directly discharged to the Patu Khola River without any treatment before dumping [26].

Developed European countries such as Germany, Austria, Belgium, Denmark, the Netherlands, and Sweden have more systematic MSW practices. In these countries only $1-3 \%$ of MSWs have been disposed of by landfilling, whereas incineration, composting, and recycling technologies have been applied for the remaining part. Table 1 summarizes disposal methods and ratios for MSW management of different European countries and Turkey. As seen from Table 1, landfilling has been used as the main waste management option in Turkey similar to other developing European countries such as Romania, Cyprus, Greece, and Malta.

This study evaluates the MSW management applications for Kocaeli, an important industrialized city of Turkey. As known, Turkey has been the connection between the Asian and European continent's and overrating environmental investments as a candidate for the European Union. In this paper, MSW management practices and problems of Kocaeli City were presented for the period 2006-12. Different MSW disposal methods were evaluated for 12 submunicipilities considering various effective factors like socio-ecomical conditions and population data. Suggestions were made for the future considering the targets presenting national and international regulations.

\section{Materials and Methods}

\section{Description of Study Area}

Kocaeli, located in northwest Turkey, lies between the $29^{\circ} 22^{\prime}-30^{\circ} 21^{\prime}$ eastern longitude and $40^{\circ} 31^{\prime}-41^{\circ} 13^{\prime}$ northern latitude. Total area of the city is $3.505 \mathrm{~km}^{2}$. The city carries geopolitical importance as it is located in junction point of roads connecting Asia and Europe. Furthermore, Izmit Bay is a natural port with a busy sea route.

Kocaeli is the fourth most developed city in Turkey after Istanbul, Ankara, and Izmir. There are 7,400 industrial enterprises in the city. Kocaeli provides $70 \%$ contribution to gross domestic product with 12 industrial zones.

Population has been rapidly increased in the region due to developing industry. Population is determined as 1,527,407 in 2012. Başiskele, Çayırova, Derince, Darıca, Gebze, Dilovası, Gölcük, İzmit, Kandıra, Karamürsel, Kartepe, and Körfez are districts of the city. All districts have different socioeconomic conditions, and population densities exhibit consequential differences.

The studied area is given in Fig. 1. As seen from Fig. 1 there are two sanitary landfills (Dilovası and Solaklar Landfills) and four MSW transfer stations (Kandira, Gebze, Körfez, and Karamürsel) located in different regions of the city.

\section{National Policies about MSW Management}

Public acts and policies are the most important facilities in MSW management. In Turkey, waste management stud-

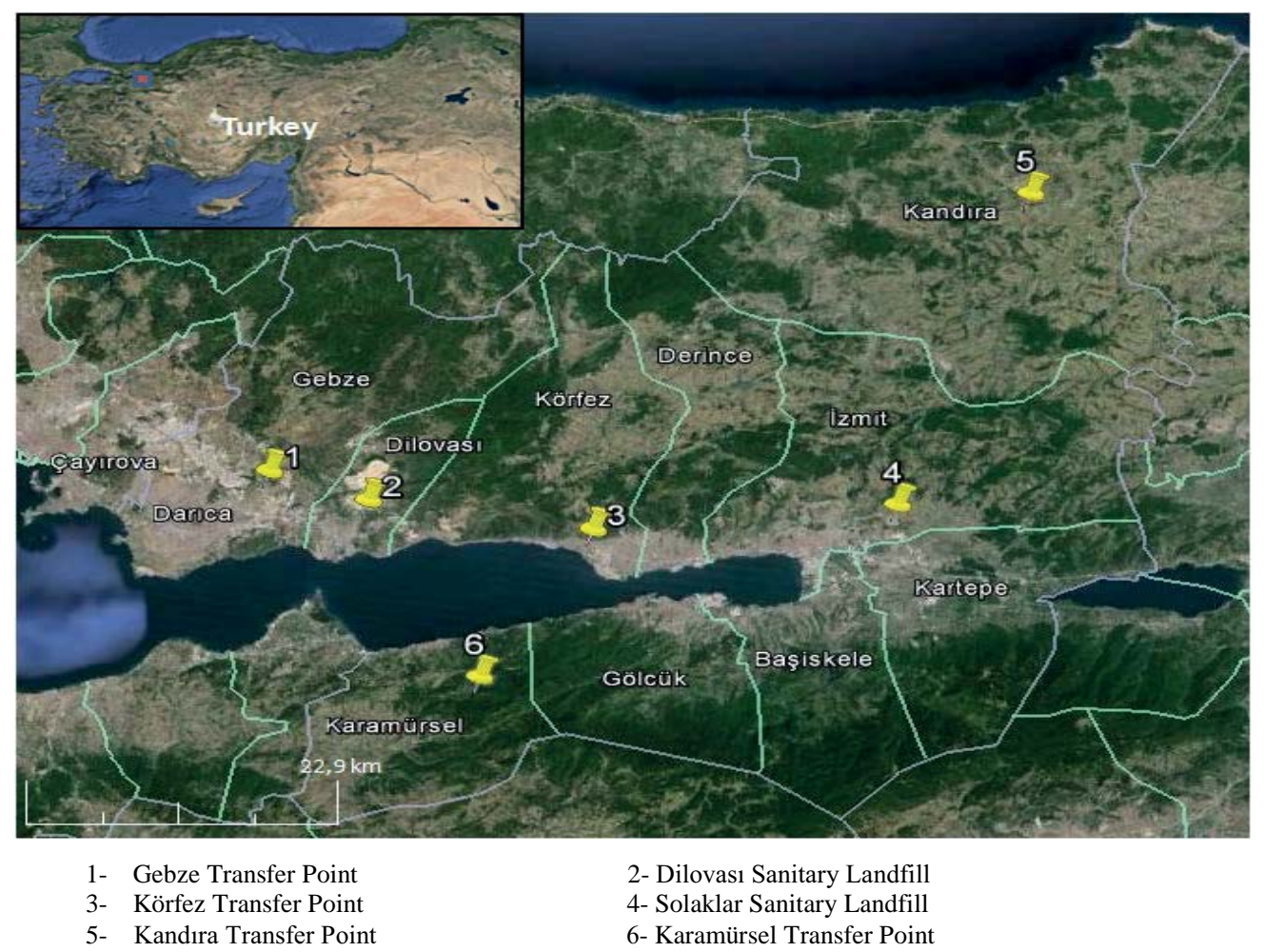

Fig. 1. Location of landfills and MSW transfer stations in Kocaeli. 
ies have been achieved with legal regulations since the 1930s and municipalities had the basic responsibilities in these applications. At the beginning, national policies and application practices were managed by Health Ministry but nowadays the Ministry of Environment and Urban Planning is carrying out these missions. Legislative acts about decomposition, collection, transport, and disposal of MSW have been published by the Governing Department of Waste Management. The 2872 numbered environmental act was published in 11.08.1983 to protect the environment with respect to sustainable development [27]. Due to the $11^{\text {th }}$ item of this act, responsibility of MSW management has been given to local authorities. Metropolitan municipalities and other municipalities were bound with law for installing and running disposal plants. Furthermore, due to the $7^{\text {th }}$ item of Solid Waste Control Act dated 14.03.1991, financial support was provided from the Environmental Protection Fund for industries using recycled materials [28]. The eighth item of the same act prohibits throwing hospital, laboratory wastes, batteries, vehicle tires, packaging wastes, electronic devices, and highvolumed wastes together with MSW. In different items of the same act, judgments were presented about collecting, transporting, and landfilling MSW.

Settling and surviving national solid waste management were emphasized strongly among the aims declared in the strategical plan of Environment and Urban Planning Goverment. According to this judgment it was aimed at increasing the recycled waste ratio, reduce waste amounts sent to disposal plants, and minimize hazardous effects of unsanitary landfilling. A cost of approximately $\$ 8$ million was projected to achieve these aims for 2014 [29].
Table 2. MSW generation amounts for different cities.

\begin{tabular}{|c|c|c|}
\hline City & $\begin{array}{c}\text { MSW Generation } \\
\text { (kg/capita/day) }\end{array}$ & Reference \\
\hline New York (USA) & 2.58 & {$[31]$} \\
\hline Vienna (Austria) & 1.50 & {$[32]$} \\
\hline Beijing (China) & 1.20 & {$[33]$} \\
\hline Singapure (Singapure) & 0.96 & {$[34]$} \\
\hline Kocaeli (Turkey) & 0.92 & This study \\
\hline Seoul (Korea) & 0.89 & {$[35]$} \\
\hline Abuja (Nigeria) & 0.58 & {$[36]$} \\
\hline Zarga City (Jordan) & 0.44 & {$[37]$} \\
\hline Dhaka City (Bangladesh) & 0.40 & {$[32]$} \\
\hline
\end{tabular}

Furthermore, basic policies and priorities in development plans of Turkey also heed solid waste management. The importance of integrated solid waste management (including separation in source, collecting, transport, recycling, final disposal) is highlighted in basic policies of the country. Sanitary landfilling is preferred as the optimal disposal method for Turkey considering general national conditions and lower enterprising costs [30].

The MSW management scheme for Kocaeli is given in Fig. 2. In the scheme, sources of MSWs and responsibilities of government and local authorities are presented.

As seen from Fig. 2, Kocaeli Metropolitan Municipality has been responsible for MSW management. IZAYDAS

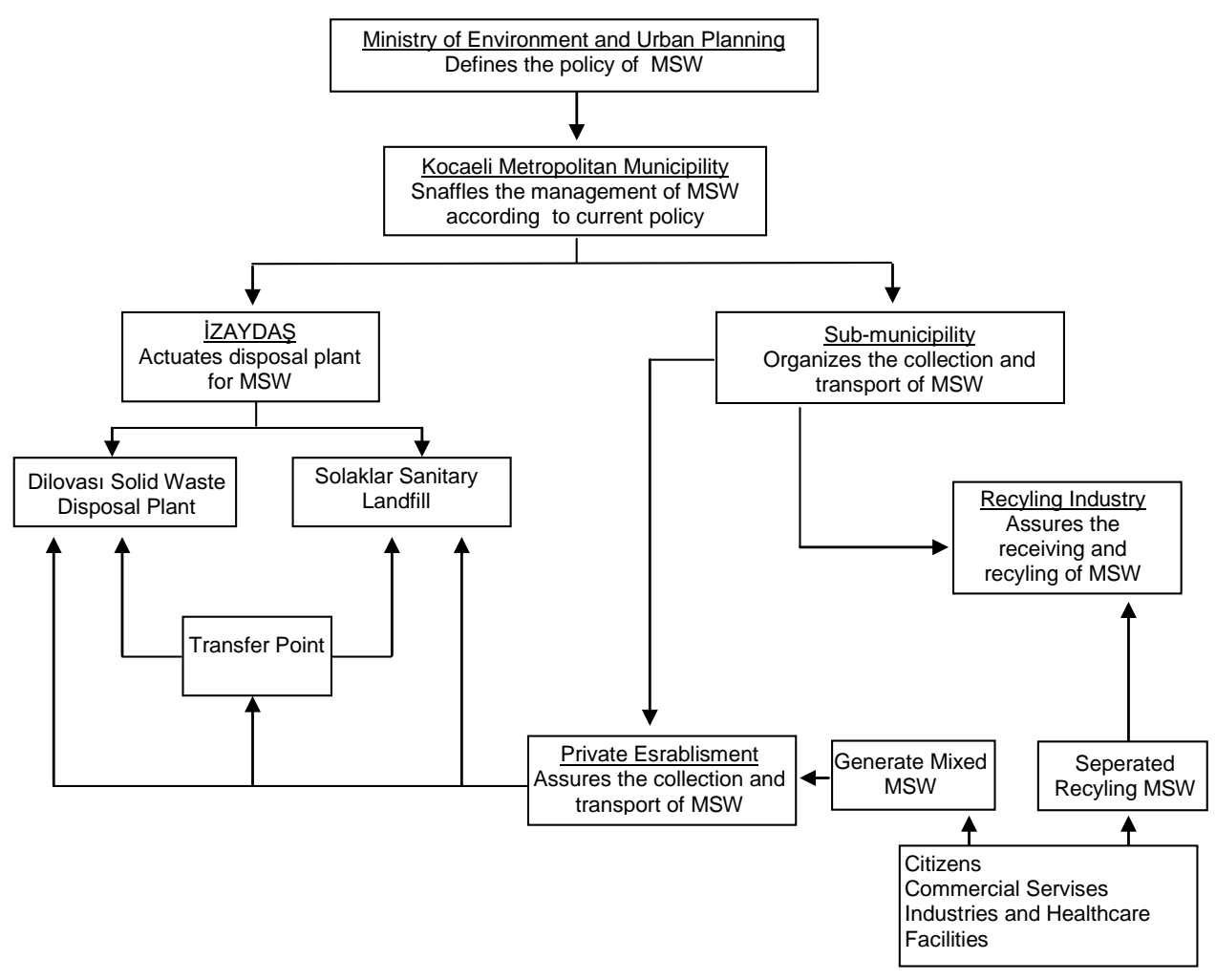

Fig. 2. Framework of responsibility and management of MSW in Kocaeli. 
was established by Metropolitan Municipality in May 1996 and provides services in incineration of hazardous waste and energy generation, regular landfilling of hazardous waste, regular landfilling of municipal waste and industrial waste, sterilization of medical wastes, marine waste management, landfilling of excavation waste, biogas, and integrated energy generation.

In Kocaeli, collection and transport of solid wastes are achieved by licensed firms in control of municipalities. MSW accumulated in containers of $0.8 \mathrm{~m}^{3}$ volume are collected by trucks with compression. Collected wastes are transported to transfer points and sanitary landfills (Fig. 1) by these trucks having 8.13 or $15 \mathrm{~m}^{3}$ volume.

\section{Results and Discussion}

\section{Generation and Composition of Municipal Solid Wastes in Kocaeli}

In order to evaluate the waste management strategies of Kocaeli, it is obligatory to monitor data of waste generation and composition. Data used in this study was obtained from the Statistical Department of Turkey and the Environmental Protection Department of Kocaeli Metropolitan Municipality. In Kocaeli, annual waste generation was increased from 451,873 tons to 547,543 tons between 2006 and 2012. Within this period, population growth rate and waste generation rate were determined as $13.7 \%$ to $21.2 \%$, respectively, for the city. Remarkable difference between these ratios can be described with growing consumption habits as a result of financial development. Increase in MSW generation is shown in Fig. 3 in terms of annual amounts per capita. Generation of waste stacks makes MSW management essential for the city.

Table 2 summarizes the MSW generation amounts for different cities. As seen from the table, MSW generation varies significantly with the development degree of the cities. MSW generation per capita is higher for the developed cities like New York and Vienna, whereas lower values were observed for undeveloped cities like Abuja, Zarga, and Dhaka. MSW generation amounts have been observed as $0.92 \mathrm{~kg} /$ capita/day for Kocaeli.

Investigating waste generation for different municipalities of Kocaeli, Kandıra was the first among the others with $614 \mathrm{~kg} \mathrm{MSW} /$ capita. It was followed by the central district, Izmit, with $380 \mathrm{~kg} \mathrm{MSW/capita} \mathrm{(Fig.} \mathrm{4).} \mathrm{Kandıra,} \mathrm{is} \mathrm{a} \mathrm{well-}$ known tourist district and in summers the population increases as a result of the arrival of wealthy tourists. Similarly, Izmit is the central district of Kocaeli where citizens live under good socio-economic conditions. Obtained results demonstrate the affect of socio-economic conditions on waste generation amounts, clearly.

Knowledge about waste characterization is also essential for optimal integrated solid waste management. MSW characterization of Kocaeli is given in Fig. 5 for 2012. In this graph, organic wastes represent the sum of food wastes and garden wastes. As seen from the figure, ratios of organ- ic and recycled wastes increase moderately in the summer season. This can be explained with the changing consumption habits in summers. Increase in food consumption (especially fruit and vegetables) in summers may be regarded as the main reason for the increase of organic waste ratio. Also, more packaged drinks are consumed in warmer months and this clearly affects the ratio of recycled wastes. On the other hand, combustible packaging materials are used for warming purposes in winter months, especially in slums with lower socio-economic conditions. This fact may explain the decrease in ratio of recycled wastes in winter.

Among the various materials that constitute the "others" group, ash is an important inorganic component for Kocaeli. The main source of ash is the use of wood and coal for warming facilities and this is the major reason for the remarkable increase in the "others" group seen in winters.

\section{Evaluation on Disposal of MSWs in Kocaeli}

Sanitary landfilling is the basic method used to dispose of generated MSW in Kocaeli. On the other hand, both metropolitan municipality and also sub-municipalities give significant importance to recycling activities.

Since August 2009, recycling of packaging wastes has been planned in Kocaeli. Papers (including cardboard and cardboard boxes), plastics, glass, and metals (including bulk metallic wastes) were collected separately in all districts [15]. Amounts of the collected packaging wastes are

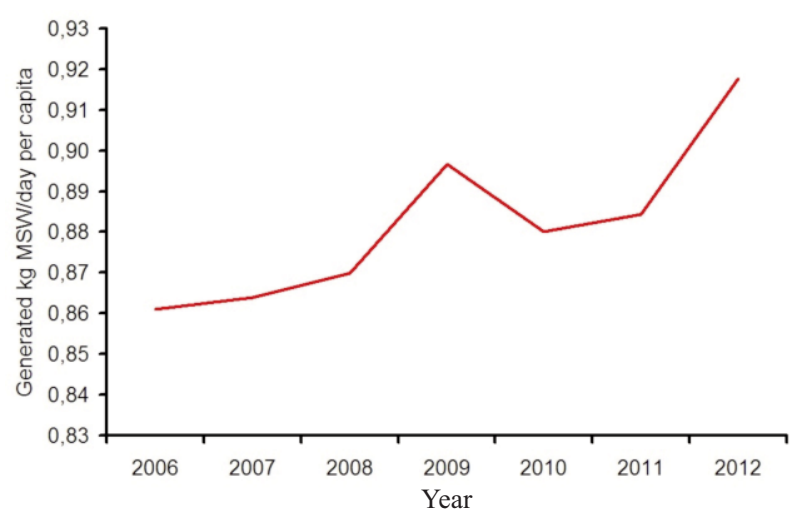

Fig. 3. MSW generation in Kocaeli for 2006-12.

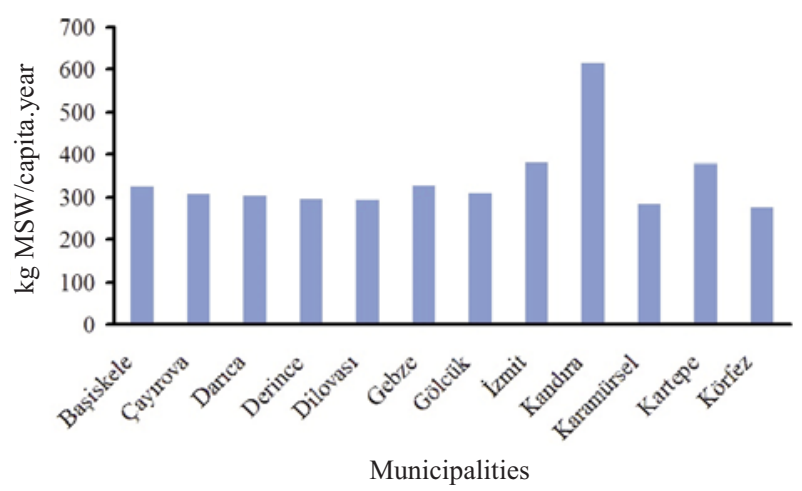

Fig. 4. MSW generation amounts for different municipalities of Kocaeli for 2012 
shown in Fig. 6 for the period 2009-12. Average 605 ton/month packaging wastes were collected in 2009 and this value has been increased to $2,333.5$ ton/month in 2012 . In other words, approximately 28,000 tons of recycled wastes were collected separately in 2012, which corresponds to $4.9 \%$ of total MSWs in Kocaeli. In European countries such as Germany, Slovakia, Belgium, and Sweden the ratio of recycled wastes are determined as 46 , 42,36 , and $32 \%$, respectively [38]. This lower ratio of $4.9 \%$ can be explained by the inadequate separate collection processes which is only based on voluntary applications.

Despite the applied voluntary project on separate collection of packaging wastes, unfortunately a total of 138,260 tons of recyclable materials have been landfilled in 2012 . Paper-cardboard, plastics, glass, and metal content of these materials have been found as $67,790,41,150,18,480$, and 10,840 tons, respectively. The average buying prices for paper, plastic, glass, and metals are determined as $\$ 80,150$, $35,120 \mathrm{ton}^{-1}$, respectively [39]. Thus the total potential economic value for recyclable materials from the waste stream in Kocaeli could be about \$5.42, 6.17, 0.65, 1.30 million $\mathrm{y}^{-1}$. Significant economic loss (approximately $\$ 13.54$ million) has occurred as a result of landfilling recyclable materials.

Another main choice of integrated waste management is incineration. In Kocaeli, although incineration has been used for disposal of hazardous and clinical wastes since 1996, there has been no practice about incineration of MSW. IZAYDAS has 35,000 tons/year waste incineration capacity. In the plant plastic wastes, used oils, drugs, and cosmetic wastes, petro-chemical wastes, PVC, solvents, furnish residues, glues, exposed products, treatment sludge, and clinical wastes are incinerated.

Sanitary landfilling is not preferred willingly, but there is unquestionable necessity for this method in all waste management systems. In Kocaeli there are two sanitary landfills planned for the MSW disposal located in Dilovas1 and Izmit. Both of these plants are operated by IZAYDAS.

The Dilovası solid waste disposal plant has been in operation since August 2007. This plant was designed as a single lot of $32,000 \mathrm{~m}^{2}$ but a new lot of $33,000 \mathrm{~m}^{2}$ area and $500,000 \mathrm{~m}^{3}$ capacity has been constructed as the older lot filled completely. Leachate formed in the plant is collected in a lagoon and transported to the leachte pre-treatment plant of IZAYDAS located in Solaklar Village of Izmit. The amount of transported leachate is summarized in Fig. 7.

- Combustable wastes $\square$ Recycled wastes Organic wastes 目Others

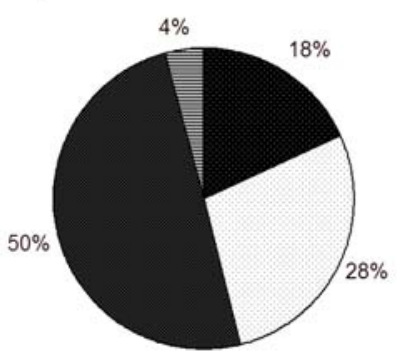

a)

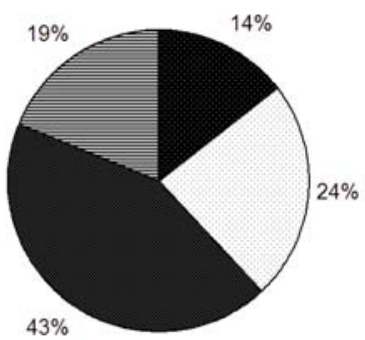

b)
Fig. 5. Solid waste characterization of Kocaeli for a) summer and b) winter of 2012.

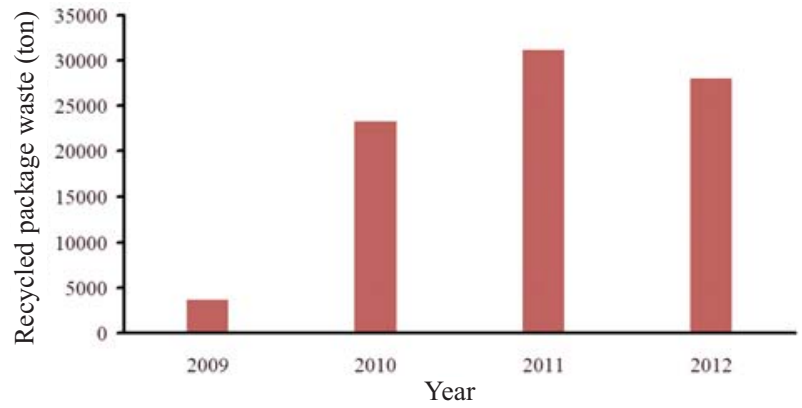

Fig. 6. Recycled package waste in Kocaeli 2009-12.

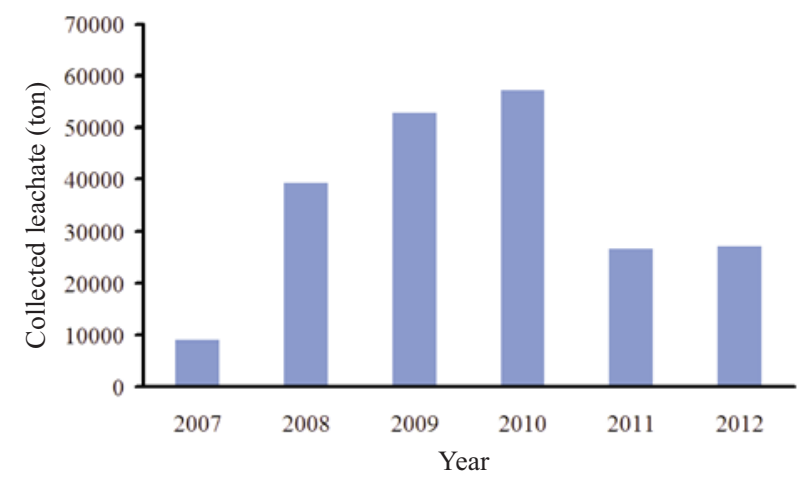

Fig. 7. Transported leachate amounts.

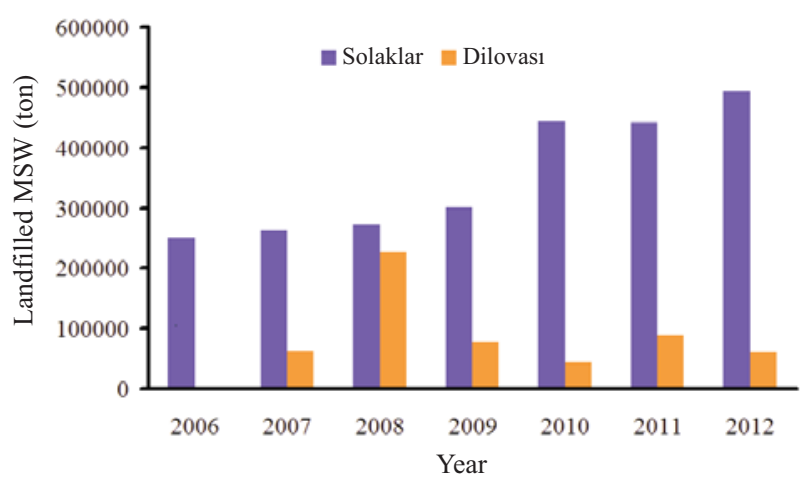

Fig. 8. Landfilled MSWs in period 2006-2012.

Solaklar Sanitary Landfill located in Izmit has been in operation since 1997. At the beginning, 7 lots were constructed for waste deposition. Later, two of six lots separated for MSWs were joined. At present there are five active lots. Two of them are filled completely, whereas two others are $98.2 \%$ filled. Nowadays the last lot of $1,580,000 \mathrm{~m}^{3}$ capacity has also been put into use.

MSW amounts landfilled in Solaklar and Dilovasi are presented in Fig. 8. As seen from the graph, landfilled MSW amounts have increased significantly in Solaklar. The rapid increase seen in 2010 can be explained with the transport from Dilovası during construction of the new lot. There are 200 hectares of remaining landfill capacity in Kocaeli and this demands efficient usage of the present space.

A plant has been constructed to produce energy from waste gas (LFG) with the built-operate approach. $\mathrm{CH}_{4}$ gas 
formed in landfilling sites has been sucked by the pumps and converted to electrical energy in the LFG unit.

At the beginning, leachate formed in the plant was pretreated with a dissolved air flotation (DAF) system, and then discharged into canalization, but today a membrane bioreactor and nanofiltration technologies have been used for leachate treatment.

\section{Conclusions}

MSW generation in Kocaeli, has been continuously increasing due to rapid population growth and economic development. Investigating the present MSW management city, it is clearly seen that sanitary landfilling is widely used, whereas unsanitary landfilling is completely deserted since August 2007. As leachate formed in landfills is treated in the Solaklar Leachate Treatment Plant and LFGs are transferred to the energy recovery unit, hazardous environmental effects are minimized. But as landfilling space is limited, this method should be obligatorily supported by other eco-friendly disposal ways such as recycling, reuse, etc.

As recycling is an important alternative for solid waste management, a project has been put into application in August 2009 on separate collection of packaging wastes in Kocaeli. Although 28,000 tons of recycled wastes were collected separately in 2012, this result is not found to be satisfactory as still remarkable amounts of valuable material have been landfilled. Inadequate collection efficiencies can be explained by the fact that the performed project was only based on voluntary applications. Legal regulations should be immediately prepared to improve separate collection of recyclable materials. Also, the application of tax collection for MSW disposal may improve the separate collection efficiencies.

When we evaluate the general situation of MSW management in Kocaeli, it is observed that $95 \%$ of MSW is landfilled and only $5 \%$ of MSW is recycled. Unfortunately, other promising technologies (composting, incineration, etc.) have not been applied in the city for waste disposal. However, MSW composition involves approximately 47\% organic wastes, which proves the appropriateness of composting technology for Kocaeli.

Incineration has not been applied for MSW disposal in the city, although there are many successful applications especially in developed countries. At present only hazardous and clinical wastes are incinerated, but this method also can be used for disposal of MSW as waste composition has approximately $16 \%$ combustible content.

\section{Acknowledgements}

The author expresses his thanks to the Environmental Protection Department of Kocaeli Metropolitan Municipality and Dr. Bilge Özbay for helpful discussions and suggestions.

\section{References}

1. SAMAH M.A.A., MANAF L.A., AHSAN A, SULAIMAN W.N.A., AGAMUTHU D'SILVA J.L. Household solid waste compositionin Balakong City, Malaysia: Trend and Management. Pol. J. Environ. Stud. 22, (6), 1807, 2013

2. SIST, State Institute of Statistics of Turkey. Envirenmental Statics, Municipal Solid Waste Generation Survey, 2010.

3. LI'AO W., TING'QUAN P., CHUAN H., HUI Y. Management of municipal solid waste in the Three Gorges region. Waste Manage. 29, 2203, 2009.

4. BADGIE D., SAMAH M.A.A., MANAF L.A., MUDA A.B. Assessment of municipal solid waste composition Malaysia: Management, practice, and challenges. Pol. J. Environ. Stud. 21, (3), 539, 2012.

5. FERNANDEZ-NAVA Y., DEL RIO J., RODRIGUEZIGLESIAS J., CASTRILLON L., MARANON E. Life cycle assessment of different municipal solid waste management options: a case study of Asturias (Spain). J. Clean. Prod. 81, 178, 2014.

6. BERKUN M., ARAS E., NEMLIOGLU S. Disposal of solid waste in Istanbul and along the Black Sea coast of Turkey. Waste Manag. 25, 847, 2005.

7. ZHANG Y., HUANG G.H., HE L. A multi-echelon supply chain model for municipal solid waste management system. Waste Manage. 34, 553, 2014.

8. TURAN N.G., ÇORUH S., AKDEMIR A., ERGUN O.N. Municipal solid waste management strategies in Turkey. Waste Manag. 29, 465, 2009.

9. AOTR, Audit Office of Turkey Republic. Evaluations of Results, of National Regulations and Applications on Solid Waste Management in Turkey- Performance Audit Report. 2007.

10. BOVE R., LUNGHI P. Electric power generation from landfill gas using traditional and innovative technologies. Energ. Convers. Manage. 47, 1391, 2006.

11. AGUILAR-VIRGEN Q., TABOADA-GONZALES P., OJEDA-BENITEZ S., CRUZ-SOTELO S. Power generation with biogas from municipal solid waste: Prediction of gas generation with in situ parameters. Renew. Sust. Energ. Rev. 30, 412, 2014.

12. LEME M.M.V., ROCHA M.H., LORA E.E.S., VENTURINI O.J., LOPES B.M., FERREIRA C.H. Techno-economic analysis and environmental impact assessment ofenergy recovery from Municipal Solid Waste (MSW) in Brazil. Resour. Conserv. Recy. 87, 8, 2014.

13. TROSCHINETZ A.M., MIHELCIC J.R. Sustainable recycling of municipal solid waste in developing countries. Waste Manage. 29, 915, 2009

14. WILSON D.C., VELIS C., CHEESEMAN C. Role of informal sector recycling in waste management in developing countries. Habitat Int. 30, 797, 2006.

15. ÖZBAY İ. Application and efficiency of packaging waste collection practices in Kocaeli, Turkey. Environ. Eng. Manag. J. 13, (3), 713, 2014.

16. ION I., GHEORGHE F.F. The innovator role of technologies in waste management towards the sustainable development. Proc. Econ. Financ. 8, 420, 2014.

17. PAGANS E., BARRENA R., FONT X., SANCHEZ A. Ammonia emissions from the composting of different organic wastes. Dependency on process temperature. Chemosphere. 62, 1534, 2006.

18. WHEATLEY A.D., SADHRA S. Polycyclic aromatic 
hydrocarbons in solid residues from waste incineration. Chemosphere. 55, 743, 2004.

19. ZHANG H., HE P.J., SHAO L.M. Fate of heavy metals during municipal solid waste incineration in Shanghai. J. Hazard. Mater. 156, 365, 2008.

20. MILUTINOVIC B., STEFANOVIC G., DASSISTI M., MARKOVIC D., VUCKOVIC G. Multi-criteria analysis as a tool for sustainability assessment of a waste management model. Energy. 74, 190, 2014.

21. HABIB K., SCHMIDT J.H., CHRISTENSEN P. A historical perspective of Global Warming Potential from Municipal Solid Waste Management. Waste Manage. 33, 1926, 2013.

22. CHEN X., GENG Y., FUJITA T. An overview of municipal solid waste management in China. Waste Manage. 30, 716, 2010.

23. ASSAMOI B., LAWRYSHYN Y. The environmental comparison of landfilling vs. incineration of MSW accounting for waste diversion. Waste Manage. 32, 1019, 2012.

24. HUI Y., LI'AO W., FENWEI S., GANG H. Urban solid waste management in Chongqing: Challenges and opportunities. Waste Manage. 26, 1052, 2006.

25. OTENG-ABABIO M., ARGUELLO J.E.M., GABBAY O Solid waste management in African cities: Sorting the facts from the fads in Accra, Ghana. Habitat Int. 39, 96, 2013.

26. DANGI M.B., URYNOWICZ M.A., BELBASE S. Characterization, generation, and management of household solid waste in Tulsipur, Nepal. Habitat Int. 40, 65, 2013.

27. MEF, Ministry of Environmental and Foresty. 2872 numbered Environmental Act, 11.08.1983, Turkey.

28. MEF, Ministry of Environmental and Foresty. Solid Waste Control Regulation, 14.03.1991, Turkey.
29. MEF-a- Ministry of Environmental and Foresty. Stratejic Plan (2010-2014), July 2009, Ankara, Turkey.

30. MEF-b-Ministry of Environmental and Foresty Performance Programme for 2010, Ankara, Turkey.

31. THEMILIS N.J., KIM Y.H., BRADY M.H. Energy recovery from New York City municipal solid wastes. Waste Manage. Res. 20, 223, 2002.

32. BRUNNER P.H., FELLNER J. Setting priorities for waste management strategies in developing countries. Waste Manage. Res. 25, 234, 2007.

33. WANG H., NIE Y. Municipal Solid Waste Characteristics and Management in China. J. Air Waste Manag. Assoc. 51, 250, 2011.

34. ZHANG D.Q., TAN S.K., GERSBERG R.M. Municipal Solid waste management in China: Status, problems and challenges. J. Environ. Manage. 91, (8), 1623, 2010.

35. YI S., YOO K.Y., HANAKI K. Characteristics of MSW and heat energy recovery between residential and commercial areas in Seoul. Waste Manage. 31, (3), 595, 2011.

36. IMAM A., MOHAMMED B., WILSON D.C., CHEESEMAN C.R. Solid waste management in Abuja, Nigeria Waste Manage. 28, 468, 2008.

37. MRAYYAN B., HAMDI M.R. Management approaches to integrated solid waste in industrialized zones in Jordan: A case of Zarqa City. Waste Manage. 26, 195, 2006.

38. EUROSTAT, 2012. Municipal waste statistics, http://epp.eurostat.ec.europa.eu/portal/page/portal/waste/ data/database. Accessed on May 05, 2014.

39. METIN E., EROZTURK A., NEYIM C. Solid waste management practices and review of recovery and recycling operations in Turkey. Waste Manage. 23, 425, 2003. 